\title{
Water supply, drainage and flood protection
}

\author{
Sarah Bell
}

Water, drainage, sewerage and flood defence infrastructure are vital for the success of any city. These systems also provide insights into how cities relate to their natural environments. Water provides a direct connection between people and landscapes in everyday urban life. The water we splash on our faces or flush down our toilets first thing in the morning provides a real, tangible connection with both the hidden landscape of urban infrastructure and the hydrological landscape that extends beyond the city. Considering water in London in 2062 is therefore more than simply a question of supply, demand, rainfall and flood risk. Our future water systems will embody our assumptions about, and relationship to, the landscapes we are part of.

Our hydrological landscapes are changing. The UK Climate Impacts Programme 2009 projections forecast that by the 2050s London's average rainfall is unlikely to change, with the most likely average rainfall between $5 \%$ more or $5 \%$ less than now. By the 2080 s the central forecast remains for no change in average rainfall, within a range of $7 \%$ more or $6 \%$ less than now. However, the timing of rainfall throughout the year is likely to change by the second half of the century, with wetter winters and drier summers (UKCP09, n.d.). This has significant implications for a water supply and drainage systems designed for relatively stable and consistent monthly rainfall. Changes in rainfall will increase flood risk, but more significant to flooding in London are forecast sea level rises of between $22.2 \mathrm{~cm}$ and $31.4 \mathrm{~cm}$ by 2060 , when our current flood defence systems will be reaching the end of their effective life spans (Environment Agency, 2012; UKCP09, n.d).

This chapter addresses three key elements of water infrastructure in London in 2062: water supply and demand, surface water and flooding. Current systems and plans from infrastructure providers and government agencies are reviewed, and alternatives explored. The chapter considers some of the forecasts for water itself, how much there will be and how we will interact with it, the institutional arrangements for infrastructure, and how the challenges of dealing with water in London over the next fifty years might provoke radical change in how London relates to its natural environment. 


\section{Water supply and demand}

London relies on river flows for its water supply. More than $70 \%$ of water used in London is abstracted from the River Thames, upstream of Teddington Weir (Thames Water, n.d). The remainder comes from other rivers, including the Lee, and groundwater. A desalination plant at Beckton is intended to be used at full capacity only during drought periods. Higher variability in annual rainfall is likely to impact on surface water flows, providing challenges for how water resources are managed for London throughout the year. The possibility of more frequent and intense droughts, resulting from greater variability in inter-annual rainfall presents further complexity for London's water managers and planners to deal with (UKCP09, n.d.).

A bigger challenge for London's water managers over the next fifty years will come from the demands of a growing population. London's water and sewerage services are provided by privatised water companies, the largest of which is Thames Water, covering most of the city. Thames Water's 2015-2040 Water Resources Management Plan forecasts a deficit between current supply capacity and future demand in London of 367 megalitres per day, or the equivalent supply to 2.2 million household customers by 2040 (Thames Water, n.d). This is consistent with forecasts for a population of between 9-10 million people by the middle of the century, approximately 2 million more than now (Greater London Authority, 2012).

The Thames Basin and much of the South East of England are currently classified as areas of serious water stress by the Environment Agency, without taking account of potential future impacts of climate change (Environment Agency. 2008). We currently take more water from the environment than it can sustain, with detrimental impacts on aquatic ecosystems and rural landscapes. There is no more water to be abstracted from the environment to supply a growing population in London. We cannot drill more boreholes, or pump more water from our rivers, without irreparably damaging our landscapes and ecosystems.

Butting up against the hydrological limits of our landscape presents us with the opportunity to rethink how we live with water in London. Thames Water is obliged to meet all demands for water from its customers, and so they must plan conservatively. Their plans for addressing the projected shortfall between supply and demand are based on reducing leakage in their networks, reducing per capita demand from customers, increasing transfers of water from other catchments and water recycling. Thames Water is currently the sole provider of water infrastructure services in London, but responsibility for water must be shared more broadly. By 2062 the structure of the water industry, and our concepts of water infrastructure and services, may have changed significantly.

\section{Demand Management}

Reducing the per capita demand for water is the lowest cost solution to addressing the projected supply shortfall. Londoners currently use more water on average that the rest of the UK: 167 compared to 150 litres per person per day (Nickson et al, 2011). The UK government has a target to reduce the national average to 130 litres per person per day by 2030, through a combination of water metering and water efficiency measures (DEFRA, 2011). Thames Water's projections for savings due to water demand measures are more conservative than government targets, and assume their customers will be using 141 litres per person per day by 2040 (Thames Water, n.d). Whilst Thames Water is understandably conservative in their estimates of the impact of demand management, it is possible that by 2062 average water demand in London could be as low as 100 litres per person per day, based on design estimates of 80 litres per person per day for zero carbon homes (DCLG, 2010).

Currently only $30 \%$ of Thames Water's customers are metered, a figure that they plan to increase to $78 \%$ by 2040 (Thames Water, n.d). Further increases in meter penetration may be possible by 
2062, particularly as hard to meter properties such as flats are demolished and reconstructed, but full penetration is unlikely considering the long life of London's building stock and plumbing systems. Thames Water estimate that metering will reduce demand by fifty megalitres per day by 2025, due to better leak detection and customer water conservation (Thames Water, n.d).

Most new water metering will be 'smart' meters. By 2062 it is likely that smart metering and sensor technologies will be considerably cheaper, allowing for much wider application. Not only does smart metering provide additional feedback to users, but it also allows for more specificity in tariffs. Ubiquitous sensing and smart metering applied to domestic water use in London 2062 could mean that customers pay more for water during a peak demand periods, or that they pay more for water used in the garden than the kitchen. Ensuring that tariffs don't unfairly disadvantage vulnerable customers or those on low incomes will be an increasingly important function of the water industry regulator and customer representative groups.

Water efficiency measures involve behavioural and technological change (Butler \& Memon, 2006). Implementing stronger water efficiency standards in building regulations and planning guidance will be a key driver for achieving high levels of water efficiency in new buildings. The Code for Sustainable Homes includes water efficiency standards, with 80 litres per person per day as the designed consumption in the highest Level 6 homes (DCLG, 2010). Retrofitting cistern displacement devices, flow-reducing valves, shower timers and other small 'gadgets' is a focus of water company efficiency campaigns. Over the next fifty years there will be greater opportunities for more substantial retrofitting for water efficiency. Even though most of London's building stock will remain, most bathrooms, kitchens and water using appliances will be replaced by 2062 . Significant water efficiency improvements could be made by setting minimum standards for fittings and appliances available on the UK market, or providing subsidies or other incentives for the most efficient devices. Retrofitting rainwater harvesting and greywater reuse systems could also be encouraged by policy and economic measures, particularly in renovation or redevelopment projects requiring local authority planning consent.

\section{Alternative Water Systems}

Currently in London, all domestic demand is met by potable supply from the Thames Water network, even though only a small proportion of water is used for drinking and cooking. Approximately $30 \%$ of water supplied is used to flush toilets, and a further $10 \%$ is used for laundry (Waterwise, n.d). These are examples of low risk water uses that could be supplied by clean water from alternative sources. Alternative supply systems provide water of sufficient quality for non-potable use, without requiring abstraction, treatment and distribution through the centralised water network. Rainwater harvesting, greywater reuse, surface water capture and other technologies provide potential sources of non-potable water in London.

Non-potable water supply systems at building or district scale in London could provide a considerable new source of water, outside the conventional infrastructure network. Rainwater harvesting or greywater reuse are relatively straightforward to implement in new buildings, but there is also considerable scope for retrofitting non-potable water supplies in London buildings, many of which have existing cisterns or header tanks that effectively supply a non-potable water system within the building, using water sourced from the potable network. Retrofitting rainwater or greywater collection, storage and filtration systems remains a considerable challenge, but the separation of potable mains supply and non-potable header tank supply in buildings reduced the need for completely re-plumbing buildings for non-potable use. The carbon emissions of rainwater harvesting systems are currently estimated to be higher than mains supply, but this is likely to have changed by 2062, as the carbon intensity of mains supply increases, and the relative efficiency of building scale systems improves (Parkes et al, 2010). 
District scale reuse of relatively high quality wastewater is another option currently being investigated as a future source of water in London (Bell et al, 2013). Rather than treating municipal wastewater, which is contaminated with human faeces, this proposition involves redistributing water that has been used for relatively low risk purposes. Domestic scale reuse of this kind might involve using shower water to flush toilets, while at a district level this could involve water from a hair salon being redistributed locally for toilet flushing in a nearby pub, or cooling water from university laboratory equipment being used for landscape irrigation. Such systems would require relatively minor treatment, but would require retrofitting distribution networks between sources and points of demand for water. Although complex, opportunities for renewal of existing infrastructure or installation of new infrastructure such as district heating, indicate that installing nonpotable water networks might be a feature of some parts of London in 2062.

Non-potable reuse of municipal wastewater is also a potential source of water for London in 2062, though it is unlikely to be widely implemented in the city. In 2012 Thames Water supplied non-potable water to the Olympic Park for toilet flushing and landscape irrigation (Knight et al, 2012). The system treats water abstracted from the northern outfall sewer, to non-potable standards, and distributes it using a dedicated network. Although the water is not treated to potable standards, the quality is much higher than required for its intended use to manage the risk of cross-connection by customers, leading to non-potable water being plumbed into potable systems such a drinking water taps. Treating sewage to this standard is energy intensive, but comparable with the total energy required for drinking water and wastewater treatment.

Alternative water systems do not easily fit within the current model of water infrastructure provision in London, which is focussed on the centralised utility company Thames Water. The UK is unique in the world in having a fully privatised water sector, and further competition in the sector may provide opportunities for a greater diversity of actors to enter the market for provision of water services over the next fifty years (DEFRA, 2011). Alternatively, greater government intervention to support alternative water systems would also open opportunities for a range of new organisations to provide new water services. For instance, wide scale implementation of rainwater harvesting systems provides a new market for servicing and maintaining these systems. Provision of non-potable water to homes and businesses could represent an entirely new infrastructure service, which could be provided be Thames Water or more specialist suppliers. Distributed water supplies for non-potable use will require new regulatory and design standards, and new structures for governance to manage public health risks and environmental impacts.

\section{New Supplies}

Such possibilities for radical reduction in demand for potable water are, unsurprisingly, not included in Thames Water's Water Resources Management Plan. As a utility with a statutory obligation to provide customers with potable water and wastewater services, their plans for new supplies focus on options for potable water, supplied through the existing distribution network. Options include building a new reservoir to increase water storage, expanding desalination, buying water from neighbouring water companies and re-using municipal wastewater. The preferred option for new supply until 2040 is re-using wastewater.

Potable reuse of water involves treating the effluent from current wastewater treatment plants to a very high standard using reverse osmosis, then returning to raw water supplies, such as to the river immediately upstream from an abstraction point, a raw water reservoir, or to an aquifer used for water supply. The water is then treated again through conventional drinking water system and distributed in the potable supply network. Reverse osmosis is an energy intensive process, effectively removing molecular scale contaminants, and is the dominant technology currently used in desalination plants. The energy required, and therefore the cost, for treating wastewater effluent is 
considerably less than seawater, which is why water reuse is preferred to desalination in Thames Water's plan.

Public acceptability of potable reuse will be central to successful implementation (Bell \& Aitken, 2006; Hartley, 2006). Proposals for similar projects in the US and Australia have failed because of public concern about drinking recycled sewage. Public acceptability of water reuse is a complex social, psychological and political problem, but research undertaken as part of Thames Water's feasibility study indicates that Londoner's are more likely to accept this new source of water than people in other places. Factors contributing to this include the urban myth that London drinking water has already been through seven sets of kidneys. Ensuring that public concerns are adequately addressed, including concerns about wider issues of water management such as leakage and demand management, will be essential if Thames Water are to build on early indications of acceptance and avoid considerable controversy.

The possibility of transfers of water to London from other catchments and water companies is explored, but dismissed as a significant new source of water for London in the Thames Water plan until 2040. Reforms in water markets in the coming decade could make water trading between companies easier, however the general conditions of water scarcity in the South East of England will constrain the amount of 'new water' this makes available to London. Increased water trading could result in agricultural or industrial users of water selling their resource allocations to Thames Water, particularly during drought years, but this is unlikely to considerably change the supplydemand balance in London.

Over the next fifty years it is possible that the idea of a 'national water grid' to move water from wetter parts of England and Wales to London will no longer be discussed in the media, and in engineering institutions, as it is unlikely that such infrastructure will be implemented without considerable investment and support from central government. More economically, ecologically and energetically favourable solutions are likely to be implemented in London, including radical demand management and water recycling, before a national scale water distribution network will be feasible. The national grid for water reflects nineteenth and twentieth century approaches to infrastructure, with visions of big engineering projects based on dams, pipes and tunnels. Such models of infrastructure will seem increasingly outdated in London in 2062, with smart city technologies helping to manage demand and providing high levels of control to improve the management of alternative water supply systems, and membrane technologies improving the efficiency of water recycling for potable reuse. Managing London's water resources within its own catchment will demonstrate a sound environmental ethic as well as being economically sensible. Schemes for pumping water across the country reflect nineteenth century determination to conquer landscapes to meet unfettered growth in demand for natural resources, which is inconsistent with movements towards sustainability, resilience and smarter use of resources and technology that current trends suggest will predominate in London in 2062.

\section{Surface water}

Changing patterns of precipitation and population over the next fifty years in London will also affect surface water runoff and flooding. More intense rainfall on paved surfaces without remedial measures will lead to more frequent localised flooding as water is unable to drain away or local drains overflow. In central London the combined sewers constructed in the second half of the nineteenth century will overflow into the Thames Tideway Tunnel, which should have been operational for more than 40 years by 2062 .

The Thames Tideway Tunnel will be one of the most significant infrastructure projects in London in the next decade. It is being constructed to stop sewage overflowing into the Thames during high rainfall events. The Tideway Tunnel was chosen in the 2000s as the most cost effective solu- 
tion to an environmental problem caused increased runoff and the inherent design of London's Victorian sewerage system. In the 1850s the most cost effective option for solving the environmental and sanitary crisis facing London was to connect households to existing surface water drains, and to intercept both rainfall and sewage, which was then flowing directly into the Thames, in large intercepting sewers that run west-east across the city (Halliday, 2001). The system design, led by Sir Joseph Bazalgette, allowed for the intercepting sewers to overflow into the Thames in times of high rainfall, to prevent sewer flooding in homes and streets. Over time the frequency of these 'combined sewer overflows' (CSOs) has increased, due to the increasing impermeability of London's surfaces, greater flows of sewage from a higher population and potentially higher frequency of intense storm events due to climate change. Overflows now occur on average fifty times a year, polluting the tidal Thames.

The Tideway Tunnel will intercept all CSOs currently discharging into the Thames. The tunnel will follow the route of the Thames from west London to Tower Hamlets, then on to Abbey Mills pumping station near Stratford, and finally to Beckton Wastewater Treatment Plant. It will be $32 \mathrm{~km}$ long, approximately $7 \mathrm{~m}$ in diameter, and up to $66 \mathrm{~m}$ below ground. The tunnel will store dilute sewage that currently overflows into the Thames, and it will be pumped out and treated at Beckton. The Tideway Tunnel is effectively an extension of Victorian infrastructure design, being the ultimate interceptor for Bazalgette's intercepting sewer system.

Alternatives to the Tideway Tunnel, such separating surface and wastewater, or increasing the permeability and local storage of surface water across London, before it enters the sewers, were dismissed by Thames Water as being too costly and unreliable. They also represent a radical departure from how surface water is managed in London. Building concrete tunnels and pumping stations, and expanding sewage treatment works are consistent with how surface water and sewage have been managed in this city since the Great Stink of 1858. In building the Tideway Tunnel 'super sewer' the water industry is doing what it knows best. However, we may have missed an opportunity to transform London's environment, buildings, streets and waterways.

The key alternative to the Tideway Tunnel promoted by its opponents is based on the principles of Sustainable Urban Drainage Systems (SUDS). SUDS aim to manage surface water where it falls, and to store water locally, rather than discharging immediately to sewers or the environment. Such measures include green roofs to absorb rainfall, rainwater tanks to store water, ponds and swales to store water in green spaces, permeable paving, and any measures that encourage infiltration and increase the capacity for the urban environment to store and treat surface water (Woods et al, 2007). These measures often deliver multiple benefits - rainwater harvesting provides a source of water for non-potable uses such as toilet flushing; green roofs provide insulation benefits to buildings; ponds, swales and other measures also increase biodiversity, reduce the urban heat island effect and can enhance green spaces for leisure, learning and relaxation. Drainage and surface water management are a key benefit of what is known more generally as 'Green Infrastructure'.

'Green Infrastructure' was rejected in favour of 'Concrete Infrastructure' as the solution to the problem of combined sewer overflows in London in the 2000s. This was largely justified in terms of cost, but green infrastructure represents a more fundamental shift in how water is managed in London. Rather than surface water being understood as a public health and environmental hazard to be removed, contained and treated, green infrastructure solutions make space for water in the urban environment. They recognise the importance of water in restoring local ecosystems and habitat, providing green space for people and relieving the urban heat island effect. However, they are more difficult to control than concrete infrastructure solutions. One big sewer is much easier for a large utility to manage than thousands of small interventions in private and public spaces and buildings across the city. The Tideway Tunnel solution affirms nineteenth century models of managing and governing water infrastructure, as much as it is a continuation of Bazalgette's interceptor design principles. 
The operational success of the Tideway Tunnel will be dependent on the cost of energy. The energy requirements for pumping and treating the additional volume of sewerage will be significant, and may become prohibitively expensive if energy prices increase dramatically. It is possible that by 2062 the Tideway Tunnel will be too costly to operate, and 'low energy' surface water management options, such as SUDS, will be ever more important. It may be energy shortage, rather than environmental or public health crises, that finally dislodges nineteenth century approaches to infrastructure in London.

It is therefore important for engineers, planners and urban designers in London to continue to pursue green infrastructure solutions to surface water management over the next fifty years, despite the presence of the Tideway Tunnel. Green Infrastructure delivers solutions to multiple environmental and social problems, as well as low energy surface water management. Although not convinced of their ability to address the scale of the problem of CSOs as reliably and cost effectively as the Tideway Tunnel, Thames Water have been supportive of SUDS in general. However, Thames Water remains fundamentally a 'Concrete Infrastructure' company, who primarily exist to provide clean water and remove dirty water in London.

Green Infrastructure delivery will ultimately be the responsibility of a wide range of actors, including local authorities, the Greater London Authority, the Environment Agency, central government, developers, housing providers, building owners, community groups, non-governmental organisations and citizens. Green Infrastructure distributes water and habitat across the city, and it distributes ownership and responsibility. Developing new governance and ownership models for Green Infrastructure will be essential in achieving the multiple benefits it can deliver in solving key environmental and resource challenges. If Green Infrastructure approaches are successful, London in 2062 may be a cooler, greener, more pleasant city, with healthy local waterways and thriving wildlife, than will be the case if Concrete Infrastructure continues to prevail.

\section{Flooding}

The greatest risk of flooding in London comes from the sea. London is situated on the Thames Estuary and at risk of flooding from storm surges in the North Sea, which can be particularly devastating if they coincide with spring high tides, as was the case in 1953 when 307 died in a flood in the Thames Estuary and other parts of southern England (Thames Estuary Partnership, n.d). Currently the land at risk of flooding in the Thames Estuary contains 1.25 million residents, eight power stations, 35 tube stations, $167 \mathrm{~km}$ of railway line and property valued at $£ 200$ billion (Environment Agency, 2012).

Constructed flood defences have a long history in London, but the most iconic feature of the city's flood defence system is the Thames Barrier, which has been operational since 1982 . The construction of the Thames Barrier was the major outcome of a review of flood defences following the 1953 flood, and its future operation is one of the key issues to be addressed by 2062 .

The sea level in the Thames Estuary is currently rising at $3 \mathrm{~mm}$ per year, a result of climate change and sinking land (Environment Agency, 2012). The south of England has been sinking and the north of Scotland rising since the end of the last ice age, rebounding after the loss of the weight of ice on the land in the north. This accounts for about $1.5 \mathrm{~mm}$ rise in relative sea level, with the remainder a result of thermal expansion of the oceans and glacial melting due to climate change (Environment Agency, 2012). By 2060 sea levels in London are forecast to be $22.2 \mathrm{~cm}$ higher than 1990 levels under a low emissions climate change scenario, and $31.4 \mathrm{~cm}$ higher under a high emissions scenario (Millin, 2010). The worst case, and highly unlikely scenario for London sea level rise, considering high levels of uncertainty in the contribution of polar and glacial ice melting on global sea levels, is $2.7 \mathrm{~m}$ by the end of the twenty-first century (Environment Agency, 2012).

Between 2002 and 2012 a major review of flood management in the Thames Estuary was conducted by the Thames Estuary 2100 (TE2100) project. This review was centred on climate change forecasts for flood risk in the estuary, but also considered economic, social and demographic change, and the 
need to maintain habitat for wildlife. The project reviewed the performance of existing flood defences in the light of climate change forecasts and developed an action plan to address current and future risks. The plan was designed to be technically feasible, adaptable to change, environmentally sustainable, economically justifiable and socially and politically acceptable.

The key recommendations of TE2 100 are that the current system of flood defences should provide adequate protection from flood risk until 2070, requiring on-going investment in maintenance until 2035, and major investment in replacement and upgrade after that (Environment Agency, 2012). The relatively long life of this protection is the result of lower rates of sea level rise than the $8 \mathrm{~mm}$ per year that the defences were designed for. The TE2 100 plan makes some assessment of options for major new investments to provide protection after 2070, the most promising of which is a new barrier across the Thames at Long Reach. By 2062 planning and construction of this new barrier, or an alternative option, should be well underway, as the current defences will be nearing the end of their effective life. The plan also addresses the need to create new habitat for wildlife in the Thames Estuary, as existing habitat sites between flood defences and the low tide water level will be squeezed out by rising sea levels.

Climate change is also likely to result in an increase of fluvial (from rivers) and pluvial (from surface water) flooding in London. Increased winter rainfall could result in up to $40 \%$ increase in peak fresh water flows at Kingston by 2080 (Environment Agency, 2012). The Thames Barrier, designed to protect against tidal surges, has been used increasingly to managing fluvial flood risk in recent years, and together with flood walls and other defences is likely to be used more frequently for this purpose. Managing pluvial flood risk is an important function for urban drainage, and over the next fifty years should be integrated with green infrastructure and SUDS implementation.

Flood defences are only one element of flood risk management. Preparing for flood events through good design and emergency planning will also be of increasing importance in 2062. Land use planning to avoid high risk development in flood plains is also vital. Vulnerability to flooding is a combination of land use planning, preparedness, and hydrology. Critical infrastructure, hospitals, aged care facilities, schools and police stations should not be planned in high flood risk areas, and by 2062 it may be possible to relocate existing facilities away from these areas. Building design in flood risk areas over the next fifty years will include resilience and local defences, such as household scale flood barriers and waterproof or low value uses on ground floors.

The TE2100 plan is notable in calling for integration between government agencies and local government authorities, as well as participation from key stakeholders including infrastructure providers, key business interests, NGOs and local communities. The plan is designed to be adaptable, subject to review every ten years and major revision in 2050 to develop more detailed plans for the end of the century. The plan outlines ten key indicators to be monitored to evaluate the on-going effectiveness of existing defences and to reduce uncertainty of key parameters such as sea level. The success or failure of this approach to planning will be evident in 2062, when the detailed planning and implementation of new defences for conditions beyond 2070 will need to be in place.

\section{Conclusion}

London has been well served by water and drainage infrastructure built in the nineteenth century and flood defences constructed in the twentieth century. These systems leave technical, environmental, economic and institutional legacies. The extent to which London is 'locked-in' to particular modes of infrastructure provision depends on a range of social and political factors, as well as the technical possibilities left open by the pipes, drains and flood walls that have been built over the last 200 years. The next fifty years will present opportunities to develop new models of the provision of water infrastructure services that take advantage of new technologies and governance structures, and reflect new understandings of the relationship between the city and the landscapes that sustain it. 


\section{References}

Bell S. and Aitken, V. 2008. The socio-technology of indirect potable water reuse. Water Science \& Technology: Water Supply. 8: 441-448.

Bell S., Shouler M., Tahir S. and Campos L. 2013. Integrating social and technical factors in decision support for non-potable water reuse networks. Paper presented at Asia Pacific Water Recycling Conference. 2 July. Brisbane

Butler D. and Memon F. 2006. Water demand management. London: IWA Publishing

DCLG. 2010. Code for Sustainable Homes Technical Guide. London: Communities and Local Government Publications. Available from: https://www.gov.uk/government/publications/codefor-sustainable-homes-technical-guidance. [Accessed 21 June 2013]

DEFRA. 2011. Water for Life: the Water White Paper. London: The Stationery Office

Environment Agency. 2008. Water resources in England and Wales - current state and future pressures. Bristol: Environment Agency. Available from: http://cdn.environment-agency.gov.uk/ geho1208bpas-e-e.pdf. [Accessed 21 June 2013]

Environment Agency. 2012. TE2100 Plan Thames Estuary 2100. London: Environment Agency. Available from: http://www.environment-agency.gov.uk/homeandleisure/floods/125045.aspx. [Accessed 21 June 2013]

Greater London Authority. 2012. Population Projections to 2041 for London Boroughs by single year of age and gender using the Strategic Housing and Land Availability Assessment (SHLAA) housing data. Available from: http://data.london.gov.uk/datastore/package/gla-population-projections-2012-round-shlaa-borough-sya. [Accessed 16 August 2013]

Hartley T. 2006. Public perception and participation in water reuse. Alexandria, USA: The Water and Environment Research Foundation.

Halliday S. 2001. The Great Stink of London. Abingdon: The History Press

Knight H., Maybank R., Hannan P., King D. and Rigley R. 2012. The Old Ford Water Recycling Plant and non-potable water distribution network. Learning Legacy. London: Olympic Development Authority. Available from: http://learninglegacy.independent.gov.uk/documents/ pdfs/sustainability/old-ford-case-study.pdf. [Accessed 21 June 2103]

Millin S. 2010. UKCP09 sea level estimates. UKCIP Briefing Notes. Available from: http://www. ukcip.org.uk/wordpress/wp-content/PDFs/UKCIP_sea-level.pdf. [Accessed 21 June 2013]

Nickson A., Tucker A., Liszka C., Gorzelany D., Hutchinson D., Dedring I., Reid K., Ranger K., Clancy L., Greaves M. and Wyse N. 2011. Securing London's Water Future. London: Greater London Authority. Available from: http://www.london.gov.uk/sites/default/files/water-strategy-oct11.pdf. [Accessed 21 June 2013]

Parkes C., Kershaw H., Hart J., Sibille R. and Grant Z. 2010. Energy and Carbon Implications of Rainwater Harvesting and Greywater Recycling. Final Report. Bristol: Environment Agency

Thames Water. n.d. Our draft Water Resources Management Plan 2015-2040. Available from: http://www.thameswater.co.uk/about-us/5392.htm. [Accessed 21 June 2013]

Thames Estuary Partnership. n.d The Thames Estuary Floods 1953. Available from: http://www. thamesweb.com/1953-floods.html. [Accessed on 21 June 2013]

UKCP09. n.d. UK Climate Projections. Available from: http://ukclimateprojections.defra.gov.uk/. [Accessed 17 August 2013]

Waterwise. n.d. At home. Available from: http://www.waterwise.org.uk/pages/at-home.html. [Accessed 21 June 2013]

Woods Ballard B., Kellagher R., Martin P., Jefferies C., Bray R. and Shaffer P. 2007. The SUDS Manual. London: CIRIA 